\title{
Annual Report of the President, 1973-74
}

An important action taken by ACRL during the administrative year just ending was the initiation of a project to assess the goals, priorities, and structure of the Association. A committee chaired by Dr. Le Moyne W. Anderson, director of libraries at Colorado State University, is pursuing the task of determining the role ACRL should play vis-à-vis library service to research and post-secondary education.

A critical self-examination is sorely needed if ACRL is to continue as a positive force in librarianship. That the environment in which the Association must perform is different today from what it was a few years ago is a truism. Change is pervasive; none of the institutions to which we are comfortably accustomed is immune. If the Association is going to operate effectively in the new environment, then it too has to change. Issues and problems must be identified, goals and priorities must be established, new programs and organizational structures must be designed.

Of course a number of issues that are properly the concern of the Association have already been identified and are being considered apart from this more general study. One project that we are especially pleased with is the internship program to prepare black librarians for administrative positions in predominantly black college and university libraries. The three-year program, which will be administered by ACRL, has been awarded a $\$ 350,000$ grant by the Andrew W. Mellon Foundation. The program will provide the interns with a variety of learning experiences in management, library operations, and administration that would otherwise be difficult for them to obtain. Casper L. Jordan, associate professor in the School of Library Service, Atlanta University, is the project director; Beverly Lynch, executive secretary of ACRL, is the principal investigator.

Improving the quality of library administration and management, particularly in regard to the relationship between the chief administrative officer and the other librarians on the staff, is something in which the profession is deeply interested. Most management techniques developed-or at least publicized-recently are methods designed to increase staff participation in matters heretofore thought to be largely -even exclusively-administrative responsibilities. Recognizing the value of investigating the implications of faculty status, collegial systems of administration, participatory management, management by objective, and so on for academic library management, the Association held a program entitled Governance in Academic Libraries at the ALA Annual Conference in New York. A related program, Management Self-Study, was also held.

Faculty status for academic librarians is a continuing concern of the Association. The Joint Statement on Faculty Status of College and University Librarians, developed by ACRL, the AAUP, and the AAC, now has twenty-nine signatories. The Association of American Colleges has yet to approve the statement it helped to prepare, but a number of state library associations have joined ACRL and AAUP in making this strong assertion for faculty status. The support of other groups is being sought and is expected. The battle is being won, but slowly.

At the 1973 Annual Conference in Las Vegas, ACRL's Board of Directors approved for publication the Model Statement of Criteria and Procedures for Appointment, Promotion in Academic Rank, and Tenure for College and University Librarians. The Model Statement provides a strong argument in support of faculty status in that it recognizes explicitly that improved status brings with it increased responsibility along with additional rights and privileges. As an expression of willingness on the part of librarians to assume these responsibilities-peer evaluation of colleagues is an example-it considerably strengthens the Joint Statement on Faculty Status.

Of the many committees active within the Association, the ad hoc committee to revise the 1959 Standards for College Libraries has been one of the hardest working. Chaired by Johnnie Givens, librarian, Austin Peay State University, Clarkesville, Tennessee, the committee spent the year exploring the possibility of devising sets of standards, which would apply, each set, to a group of institutions sharing easily identifiable and readily defensible characteristics. This approach appears to answer some of the criticisms of the 1959 formula, and should prove acceptable to those concerned with evaluating library collections. Since objective criteria of this sort tend to be widely used by accrediting agencies, funding agencies, and the like, the standards are extremely important, and all of us watch the progress of this hard working committee attentively. The committee was supported in its 1973-74 work by a $\$ 9,250$ grant from the J. Morris Jones-World Book Encyclopedia-ALA Goals Award, and will be supported in 1974-75 by an additional $\$ 12,000$ from the same award. Revising the 
1959 Standards is an important association project pertaining to collection development; publication of the CORE Collection, sometimes called $B C L I I$, is the other. This eagerly awaited listing of 40,000 titles went to the publisher (ALA) shortly before the Annual Conference in New York. The road to the finished product has been somewhat rocky, but with the end in view, everyone involved in the project has a right to be pleased with it. Virginia Clark did some of the final editing from London while Beverly Lynch firmly enforced the schedule in Chicago. Those of us who have utilized $B C L$ extensively in collection development know the importance of the CORE project, and have grown progressively anxious to see the six-volume sets come in the door, will be very happy to have them in hand.

In another publishing matter, Richard $\mathrm{M}$. Dougherty, editor since 1969 of College \& $R e$ search Libraries, asked to be relieved of the editorship effective July 1974. ACRL's Board of Directors accepted Dr. Dougherty's resignation with deep regret, and asked Richard D. Johnson, director of libraries, State University College, Oneonta, New York, to assume the post. Mr. Johnson has previously edited the Stanford Library Bulletin, the Honnold Library Record, and the California Librarian. In 1968 he won an H. W. Wilson Library Periodicals Award for his work on the latter publication, and we look forward with pleasure to his tenure as $C R L$ editor.

Having listed the accomplishments of the Association this past year, I would like to note an area of librarianship that was not looked at closely by the Association, but which appears to be undergoing significant change in the academic world. I refer to the fact that public academic libraries are being threatened by an absentee management revolution. Academic libraries are not under siege by dissidents and anarchists but by mild-mannered bureaucrats who are imposing a managerial revolution upon. the academic world and upon libraries in particular.

The absentee managerial revolution, consisting of statewide systems of budgeting and personnel, single computer systems, and standardized course offerings and academic calendars, has been the result of the trend toward the extension of governmental control in all aspects of life. One system leads inevitably to another as coordinating boards and commissions enlarge and extend their powers until the tangle of rules and decision chains becomes almost impossible to follow. This situation is acutely obvious in the case of academic libraries. A student with a problem cannot lodge a complaint with the director of the library or even with the president of the college or university. The solu- tion to the problem is entirely out of their hands, lost somewhere in the maze of bureaucracy, usually at the end of a long trail of red tape. Excellence is no longer a visible goal.

I would like to stress the dangers of considering the college and university library as just another department in just another state agency. This kind of reasoning leads to judging the merits of a college or university library upon the utility of its book collection rather than upon the quality and to judging librarians not upon their individual abilities and contributions but rather upon conformance to some utilitarian civil service norm.

One particularly unfortunate example of such an attitude is the imposition of uniform personnel standards by an impersonal statewide system. A detailed position description sent down from some remote state agency cannot reflect the actual needs of an individual library in an individual situation. In the same way that teaching faculty are being forced to maintain legislatively mandated teaching loads, academic librarians are being forced to conform to job descriptions which do not necessarily reflect their backgrounds, local situations, or particular abilities. The result is a stultified and sterile atmosphere with little room for innovation or growth.

The absentee managerial revolution in academic libraries is not producing more efficient administration or higher quality "products" because academic libraries are not "business." Trying to treat an abstract concept like education as if it were a product can only result in confusion and ultimately in a decline in the quality of the university and in libraries. Nor can a library be thought of as a "business." This kind of reasoning has led to the consideration of the university as a kind of "knowledge factory" with raw material in the form of students being turned-by the use of complex machinery in the form of books, laboratories, and classrooms-into a marketable end-product called a graduate. The quest for knowledge has no place in such a factory where workers called "faculty" are not interested in leading students toward knowledge, but rather in measuring the "value added."

A university library is a very special place. It is not possible to standardize libraries without losing more than is gained. Some aspects of the systems approach may be necessary in order to save money, but the enforcement of rigid centralized selection policies and statewide personnel practices, with little regard for the highly individualized personalities of individual campuses, can only have the end result of lowering the high standard of public education.

This new managerial revolution used cau- 


\section{IMSTAMTAMEEOUSIY That's how last SGISEARCH Potrieves the information you need from the life sciences journal Ilterature.}

When you need the

literature search now. When you need to know about the most recent developments in a field. When you have a complex search that conventional library techniques can't handle. That's when you need ISI's new

SCISEARCH, the computerized on-line retrieval file that gives you quick, easy, economical access to one of the world's largest sources of information on the life sciences journal literature. To provide more current, more complete information to your research scientists. To serve them more quickly and efficiently. To save time for you and your staff. To lower your library's searching costs.

\section{ISI's huge life sciences}

tile is being made available to researchers, librarians and information specialists within the U.S. and Canada through the widely used SDC Search Service, an on-line, interactive retrieval service of System Development Corporation.
Casy Access. Stressing ease 5 of access, SDC's on-line retrieval program-ORBIT -will permit you or your search specialist to conduct extremely rapid searches through a two-way communications terminal located in your own facilities. In a typical 10 to 15 minute "conversation" with the computeryou type simple English Ianguage statements-you can easily formulate your questions, examine preliminary results, employ on-line dialogue to improve your understanding of the file's contents, then refine and tailor your search to specify exactly what you want from the file. And because the system is tied-in to a nationwide communications network, most subscribeirs will be able to link their terminal to the computer in Santa Monica, California, through a local phone call.

\section{1} ver 400,000 Items. Covering every article from about 1,100 of the world's most important life sciences journals, SCISEARCH will initially offer a searchable file of over 400,000 items published since April, 1972. Each month, approximately 16,000 new items will be added until the average size of the file will be about one-half million items and cover $2 \frac{1}{2}$ years. This monthly update means you can search current literature many months before it appears in printed indexes.
Tough Searches Made Easy. To assure you maximum retrieval efficiency in dealing with this massive file, SCISEARCH enables you to make the simplest to the most complex literature searches. For example, you can search by title words, word-stems, word-phrases, authors, and organizations or by any combination of these techniques. In addition, citation searching-an exclusive feature of ISI's data file-permits you to locate additional items about a subject if you know about an earlier publication on the same subject.

That You'll Get. For every item retrieved, you can receive a full, on-line bibliographic description. This includes: all authors, full article title, journal citation, language indicator, a code for the type of item (article, note, letter to editor, review, etc.), an ISI order number and all references from the bibliography contained in the retrieved article. You can use the order number to place on-line orders for copies of articles from ISl's Original Article Tear Sheet service (OATS ${ }^{\oplus}$ ).

Cor More Information. We'd like to tell you more and actually demonstrate how SCISEARCH can help you and your colleagues. Simply call Mel Weinstock at (215) 923-3300. Or write him at the address below.

Qiena is! 
tiously can produce some economies. As it is presently used as a harsh remedy, it threatens to convert free-standing, self-directing universities and their libraries into homogenized state systems. The old faiths of institutional initiative, academic freedom, flexibility of approach, and innovation are being stifled by red tape. Initiative is crippled, ultimate responsibility is diluted, and true accountability, ironically, is destroyed-all in the name of "management overkill."

To sum up the year, the Association has sought ways to respond to the multitude of problems faced by academic librarians today. We have addressed ourselves to some of them, certainly not all; indeed, some are yet to be discovered, as Mr. Anderson's committee will doubtless find. Perhaps no demonstration of our efforts to get to the grass roots, to get to know what the membership sees as most important, has been as well received as the encouragement of local chapters. Within a framework of such chapters, ACRL members can meet and discuss matters of local, regional, and

\section{Christopher Wright Assistant Director ALA Washington Office}

Commissioner of Education Dr. John Ottina had just recommended to the Senate subcommittee that academic library programs be phased out, suggesting that the administration's proposed Library Partnership Act would soon take the place of traditional federal support for libraries. From across the felt-covered table Senator Norris Cotton fixed him with a baleful eye. "Do you really think it will make any sense to let proven programs die while you wait around for authorization on this?" the New Hampshire Republican asked.

The question from the ranking Republican on the Senate's Subcommittee on Labor-HEW Appropriations underscores the basic problem with the administration's sole venture into library support. To many people the proposed legislation looks like a diversionary tactic by an administration determined to kill off traditional federal aid to libraries.

A draft of the bill now making the rounds in Washington says its purpose is "to encourage and support innovation and improvement in library and other information services and to promote the equalization of access to such services within communities and among local, state, and regional jurisdictions through various national concern in a manner that is impossible for the membership at large or the divisions to do. George Bailey, associate library director, the Claremont Colleges, Claremont, California, chairs the ad hoc Committee on the Development of Chapters in ACRL.

As outgoing president, I would like finally to express appreciation on behalf of the Association and offer my own warm thanks to the many people who helped make this year the successful one that it was: the other officers, the hard working staff at ALA headquarters, and those who chaired and otherwise served ad hoc and standing committees. The membership owes its biggest debt of gratitude by far to Beverly Lynch, ACRL's tireless executive secretary, who worked long, arduous hours on all of the Association's projects, traveled ceaselessly on the Association's behalf, attended meetings interminably, and who deserves the major portion of the credit for steering the Association through the year.

\section{Inside Washington}

means, including cooperative activities among libraries and other information resources."

That sounds a great deal like two library programs already on the books-the research and demonstration part of the Higher Education Act (HEA II-B) and the interlibrary cooperation part of the Library Services and Construction Act (LSCA III).

According to the current draft of the bill, money would be designated for:

"(1) extending library services to the handicapped, institutionalized, and economically disadvantaged persons and identifying the information needs of such persons;

"(2) designing and developing interlibrary cooperative services and activities;

"(3) designing and demonstrating exemplary projects under which libraries may become non-traditional community resource centers;

"(4) integrating library and basic education training services; and

"(5) demonstrating improved methods of library administration and fiscal control."

No one can quarrel with a program designed to provide better service to the handicapped or to make libraries into modern, efficient institutions serving schools and communities with added purpose.

The problem is not in what the Library Partnership Act will do, but in what it will not do if it replaces existing legislation. 